\section{Chapter}

[1]

\title{
Deteriorating impacts of emerging water pollutants on biological diversity
}

\begin{abstract}
Ashish Uniyal
Uttaranchal (P.G.) College of Bio-Medical Sciences and Hospital, Dehradun 248001, Uttarakhand, India
\end{abstract}

Water pollutants are the substances that affect the physicochemical and biological properties of water that cause undesirable and great destruction of the ecosystem on earth. Industrialization, urbanization, and agriculture activities impact the quality of freshwater and also decrease the availability of freshwater. Water is the safeguard of biodiversity but the pollutants present in water accumulate in the body of the living organism and causes negative effect directly or indirectly on plants, animals, and human being. Excess plant food, herbicides, and pesticides once washed by rain into rivers cause danger to life. The control of water pollution increases the quality of water using various conventional treatments which reduces the pollutants that cause the reduction of water-borne diseases and increases physiological activities in the organism. Effective water quality prevention increases the economy and development of aquatic life as well as biodiversity. Biodiversity is the key to the earth ecosystem and nowadays the conservation of biological diversity is the biggest challenge. Thus, the present chapter enlightenment the impacts of various water pollutants on biodiversity and developing way of mitigation. The immediate actions need for making effective policies and implementation of acts reduce the pressure on the freshwater ecosystem.

Keywords Biodiversity, Conservation, Industrialization, Pollutants, Urbanization 


\section{Introduction}

Water is one of the most important sources of life and out of $75 \%$ only $3 \%$ freshwater present on earth (Pathak, 2018). In India, water pollution is the most serious problem due to the contamination of various toxic, organic, biological, and inorganic pollutants (Murty and Kumar, 2011). In 21 century, water pollution is the universal challenge for developing and also for developed countries that causes various diseases in the human population and the polluted water also affects biodiversity (Bassem, 2020). Rivers, streams, lakes, ponds, and reservoirs are the resources of freshwater and due to the increase of the human population, urbanization and industrialization continuality affect the resources of freshwater and decrease the availability of freshwater (Pathak, 2018; Cherian and Shahare, 2011).

Chemical, physical, radioactive waste material, pathogens from industrial effluents, agricultural run-off, domestic sewage, construction activities, and mining activities causes contamination in freshwater and affect the freshwater biodiversity (Richardson et al., 2007). However, $70 \%$ to $80 \%$ of municipal wastewater is discharged untreated into freshwater bodies and also many industrial activities are known for its responsibility for dumping millions of tons of heavily pollutants such as solvents, heavy metals, toxic sludge every year but the pollution of water does not only affect the water bodies, they also adversely affecting the land, agriculture, aquatic life and human health to a greater manner (Vishwanath et al., 2017; Bassem, 2020; Kumar et al., 2020).

According to Odum (1971), pollution is undesirable changes within the physical, chemical, and biological characteristics of our air, land, and water which can harmfully affect human life, industrial progress, living conditions, and cultural assets. Biodiversity of aquatic organisms is greatly affected by the various types of pollutants differently and they are sensitive to any variation in the aquatic environment that causes drastic responses like effect in metabolic activity, reduction in reproductive capacity, migration to suitable habitat, and death. Moreover, pollution with heavy metals impacted the whole aquatic biodiversity. According to Bouraie (2010), in 1992, 50\% of industrial waste which refers to the metallurgical industry effect the aquatic organism especially fishes.

The term biodiversity is an essential component of all water systems and the relation between water pollution and biodiversity will be covered through the following topics; Importance of biodiversity and its relation to ecosystems than their main threats. Assessment of biodiversity impacts on ecosystems and communities is required to be elucidated and eventually what are the conservation challenges facing biodiversity.

\section{Key source responsible for water pollution}

In 21 centuries, the quality of freshwater is the major challenge facing by a human being, freshwater and marine organisms, that causes negative impacts on human health in addition to other respective 
organisms (Fent, 2013). Moreover, the quality of water changes either directly or indirectly affects the immune system of fishes. (Poulin, 1992; Abdel, 2018).

Water pollution effect the activity of normal uses of water in daily life for agriculture, aquaculture, public water supply, industry, etc. There are many sources of aquatic pollutants viz; industrial effluents, municipal sewage, herbicides, and pesticides from agriculture wastewater that harms aquatic biodiversity and also terrestrial organisms. Moreover, according to Kumar (1997) and Pathak (2018) the source of water pollutions is:

Domestic and municipal pollutants: The sewage is the largest source of water pollution that contains various components such as garbage, soaps, detergents, waste food, human, and livestock excreta.

Industrial pollutants: Industries are liable for discharging their untreated effluents into rivers having heavy toxic metals like chromium, arsenic, lead, mercury, etc. along with hazardous inorganic waste material like acids, alkalies, cyanides, chlorides phosphate, nitrate, sulphate, and trace elements such as $\mathrm{Hg}, \mathrm{Cd}, \mathrm{Pb}, \mathrm{As}$, Se, etc and organic waste material like oil, petroleum compounds, pharmaceuticals, synthetic organic compounds. Petroleum products are widely used for fuel, lubrication, plastics manufacturing, etc.

Agricultural waste: Agriculture wastes are enrichments of manure, fertilizers, insecticides, pesticides, etc, wastes or silt are drained as run-off from agricultural lands. The water body receiving large quantities of fertilizers (phosphates and nitrates or manures becomes rich in nutrients which results in eutrophication and consequent depletion of dissolved oxygen.

Radioactive wastes: Water bodies are polluted by accidental leakage of waste material from uranium and thorium mines, nuclear power plants, and industries such as $\mathrm{Ra}^{226}, \mathrm{Sr}^{90}, \mathrm{Cs}^{137}, \mathrm{Ba}^{140}, \mathrm{Kr}^{85}, \mathrm{Co}^{60}, \mathrm{Mn}^{65}$, $\mathrm{Pu}^{239}$ research laboratories and hospitals which use radioisotopes.

Thermal sources: Various industries, nuclear power plants, and thermal plants utilize coal or nuclear fuel and require water for cooling, and the resultant hot water is often discharged into rivers or lakes.

Sediments: Soil particles are carried to streams, lakes, or oceans from the sediments. A large number of sediment pollutants affect water quality.

\section{Water parameters as an indicator of pollution}

Water pollution is taken into account in normal conditions on the idea of bad odor, uncontrolled growth of weed, and a decrease in population of fishes and by the bad taste of the beverage. Water could also be called polluted when the subsequent parameters stated below reach beyond a specified concentration in water. The physicochemical properties of water are studied with standard methods which are given in APHA $(1989 ; 2005 ; 2012)$.

- Physical parameters like color, odor, turbidity, taste, temperature, and electrical conductivity constitute the physical parameters and are good indicators of contamination. For instance, color 
and turbidity are visible pieces of evidence of polluted water while an offensive odor or a bitter and different than normal taste also makes water unfit for drinking. Color is necessarily harmful and is undesirable in potable water.

- Chemical parameters include the number of carbonates, sulfates, chlorides, fluorides, nitrates, and metal ions. These chemicals form the entire dissolved solids, present in water.

- Biological parameters include matter like algae, fungi, viruses, protozoa, and bacteria. The life forms present in water are affected to an honest extent by the presence of pollutants. The pollutants in water may cause a discount within the population of both lower and better plant and animal lives. Thus, the biological parameters give an indirect indication of the quantity of pollution in water.

\section{Impacts of water pollution on biodiversity}

Biological diversity or biodiversity term is referring to all aspects of variability evident within the living world, between individuals, populations, species, communities, and ecosystems. According to United Nations Convention on Biological Diversity, the definition of biological diversity is "living species variations from sources that include terrestrial, marine, different aquatic ecosystems and also ecological groups to which they belong: including diversity among species and also ecosystems (UNEP, 1992). There are up to about 100 million species on the earth, of which humans know only about 1.6 million species. Several of these species are known to be threatened, and an estimate puts the number of such threatened species at 41,415 . It is also recognized that several species are already extinct and such extinctions are still happening (IUCN, 2019).

On earth, water is that the most vital supply of life most of the species pay their life in water. However, water bodies like ponds, stream, rivers, and oceans mistreatment many ways in which result from the negative impacts on diverseness. The Contamination of streams, lakes, seas, underground water, or oceans by substances, is harmful to live beings and result in $\mathrm{H}_{2} \mathrm{O}$ diverseness (Richardson et al., 2007). The expansion of the human population, industrial and agricultural practices is that the major causes of pollution. waste matter is that the biggest waste matter of $\mathrm{H}_{2} \mathrm{O}$ that causes waterborne diseases and each year five million deaths per annum are often attributed to waterborne diseases (Viswanath et al., 2017). Unhealthful (disease-causing), microorganisms (bacteria, fungi, protozoa, algae) enter the water system through waste matter creating it infected. Typhoid, cholera, stomach flu, dysentery, polio, hepatitis, and cancer area unit normally caused by drinking infected water. The watercourse of Ganges receives wastes from textile, sugar, paper and pulp mills, tanneries, rubber, and chemical industries. Most of those pollutants non-perishable thus harm the expansion of crops and therefore the impure water is unsafe for drinking functions (Pathak, 2018). Excess plant food, herbicides, and pesticides once washed by rain into rivers cause danger to life. Detergent is additionally terribly unhealthful to marine 
life once washed into the water. Some pesticides like pollutant area unit notably dangerous once allowed into bodies of water as a result of its concentration will increase the organic phenomenon (Pathak, 2018). The livestock sector is responsible for the majority of the most common pollutants called Nitrogen and phosphorus, in Europe $73 \%$ of water pollution from these sources can be attributed to livestock production (Leip et al., 2015).

Pesticides and Insecticides: If not applied correctly, pesticides can end up in watercourses via similar pathways to the fertilizers mentioned above. Studies back in the mid-90s revealed that $90 \%$ of water and fish samples from waters in the USA contained one or more pesticides. Chlorpyrifos is a common contaminant in urban streams and is toxic to fish. Other pesticides such as trifluralin and glyphosate which are common in everyday garden weed killers might not directly kill fish but they can lessen the chance of survival which can impact the population as a whole (Liong et al., 1988). The impacts of pesticides on biodiversity tend to be worse for non-flowing water bodies such as ponds and lakes where the substances aren't washed away and where wildlife can't re-populate areas as easily.

Heavy metals: Factories producing plastic, hydroxide and a few fungicides and pesticides unleash mercury (a serious metal) alongside different effluents in the close water body. Mercury enters the organic phenomenon through microorganisms, algae, and fish eventually into the organic structure. Consumption of water made in nitrates is dangerous for human health particularly for tiny youngsters (Pathak, 2018). Serious metal pollution of water will originate from several sources, from mining to cars, to cement production. Serious metals embody metals like mercury, arsenic, and metallic element that all have the characteristic of not breaking down simply once within the setting. These metals are found to own impacts on fish species impacting behavior and survival rates (Sehar et al., 2014). When toxic substances enter into water reservoirs, they get dissolved or suspended in water or get deposited on the bottom. When freshwater is supplemented it results in an abnormal increase in water plants. The level of mercury in fish is most dangerous for humans, especially for pregnant women and infants. Mercury interferes in the development of the control nervous system, leading to long-term side effects. Industrial waste contains toxic compounds damaging the health of aquatic lives. They may cause minor effects or maybe fatal also. Heavy metals from industrial processes can accumulate in the water reservoirs. These are toxic to fish, shellfish, other aquatic lives, and humans eating them. Heavy metals like $\mathrm{Cd}$ may cause vomiting, abdominal pain, loss of consciousness, softening of bones, etc. $\mathrm{Pb}$ may cause retarded development, Brain damage, uncoordinated, body movements. Effects of heavy metals $(\mathrm{Zn}, \mathrm{Cu}, \mathrm{Cd}, \mathrm{Pb}$, and $\mathrm{Hg}$ ) were examined in some commercial fish species collected from the Egyptian coastal region along the Mediterranean Sea (Shreadah et al., 2015). Bangladesh has some of the most polluted groundwater in the world. In this case, the contaminant is arsenic, which occurs naturally in the sediments. Around $85 \%$ of the total area of the country has contaminated groundwater, with at least 1.2 million Bangladeshis exposed to arsenic poisoning and with millions more at risk. Each year, plastic 
waste in water and coastal areas kills up to 100,000 marine mammals, 1 million sea birds, and countless fish (Vishwanath et al., 2017; Kumar et al., 2018).

Oil and spill: Crude oil and the different connected product usually get into the water by accidental spillage from ships, tankers, pipelines, etc that causes. a significant water waste matter has been oil spilled in massive quantities from tankers of broken oil pipes from oil industries that kill ocean weeds, mollusks, marine birds, crustaceans, fishes, and different ocean organisms that function as food for humans. Oil enters the water from several sources however it's the most important impact on life throughout an oversized 'oil spill' event. This is often typically once oil is being transported during a ship across the ocean and somehow spills an oversized quantity of the load, inflicting mayhem on the compact system. While it's the birds and bigger animals that show the foremost visible effects of such an incident, scientists counsel the bigger impacts on diverseness area unit caused by the adverse effects on life within the deeper oceans.

Radioactive elements: Radioactive materials enter living beings through water and food, and should be accumulated in blood and sure important organs. Higher temperature lowers the dissolved element level (which is incredibly essential for marine life) by decreasing the solubility of the element in water (Pathak, 2018). However, consistent with Kibria (2016), various classes of pollution result in the water quality of watercourse and diverseness of watercourse (Table 1). they're acid mine drain, bacteria, cold pollution, dirt, endocrine-disrupting chemicals, nutrients, polycyclic aromatic hydrocarbons, polybrominated diphenyl ethers, polychlorinated biphenyls, polychlorinated dibenzo-p-dioxins, polychlorinated dibenzofurans, pesticides, herbicides, fungicides, prescribed drugs, phthalates or plastic, trace or serious metals and transboundary pollution. In Asian countries, most impure rivers area units are found in Bharat, Bangladesh, China, Indonesia, Philippines. The water contaminated water by numerous pollutants affects human consumption, irrigation, agriculture, food process, eutherian mammal drinking, cultivation, and aquatic ecosystems protection. Loss of biodiversity due to the impact of water pollution harms the environment too. The direct and indirect way of effecting water pollutants disrupts biological diversity and also affect the ecosystem. The immediate actions need for making effective policies and implementation of acts reduce the pressure on the freshwater ecosystem. Awareness and education programs play an important role in the protection of rivers from pollution.

\section{Conclusion}

Nowadays, water pollution is the greatest environmental problem that affects biological diversity. Water pollution is enormous by the human contribution that affects the quality of water in various ways such as dumping of waste material, industrial wastes material, bathing and washing of clothes, etc. in rivers and lakes. Maintain the quality of water and practicing the habits of cleanliness, efforts for 
Table 1. Different types of emerging water pollutants and their effects on biodiversity (Kibria, 2016)

\begin{tabular}{|c|c|c|}
\hline $\begin{array}{l}\text { Emerging } \\
\text { pollutant }\end{array}$ & Sources & Effects \\
\hline $\begin{array}{l}\text { Acid Mine } \\
\text { Drainage } \\
\text { (AMD) }\end{array}$ & $\begin{array}{l}\text { The outflow of acidic water from metal } \\
\text { mines or coal mines. AMD waters can } \\
\text { have very low pH (-3.6), with high } \\
\text { sulfate, iron, and aluminum, and ele- } \\
\text { vated copper, chromium, nickel, lead, } \\
\text { and zinc, and elevated calcium, mag- } \\
\text { nesium, sodium, and potassium. }\end{array}$ & $\begin{array}{l}\text { AMD affects water quality } \\
\text { AMD containing high metal and salt concen- } \\
\text { trations resulting in toxic effects on aquatic } \\
\text { biodiversity (fish, invertebrates). } \\
\text { AMD Kill freshwater organisms. } \\
\text { AMD causes unfit for drinking, irrigation, and } \\
\text { industrial use. }\end{array}$ \\
\hline $\begin{array}{l}\text { Bacteria } \\
\text { (Escherichia coli) }\end{array}$ & Contaminated water & $\begin{array}{l}\text { Contaminated water causes depletion of dis- } \\
\text { solved oxygen in water (foul dour) health } \\
\text { effects. } \\
\text { Contaminated water causes outbreaks of wa- } \\
\text { ter-borne diseases. }\end{array}$ \\
\hline $\begin{array}{l}\text { Coldwater } \\
\text { pollution }\end{array}$ & $\begin{array}{l}\text { Coldwater being released into rivers } \\
\text { from large dams. }\end{array}$ & $\begin{array}{l}\text { Coldwater pollution may affect the richness of } \\
\text { native freshwater fish species. } \\
\text { Coldwater reduces the growth of native fish, } \\
\text { their survival, and breeding. }\end{array}$ \\
\hline Dirt & $\begin{array}{l}\text { Floods, rain washes, removal of trees } \\
\text { (erosion) }\end{array}$ & $\begin{array}{l}\text { Dirt affects water quality and photosynthesis } \\
\text { in aquatic plants. } \\
\text { Dirt may clog the gills of fish. } \\
\text { Dirt reduces the fish population. }\end{array}$ \\
\hline $\begin{array}{l}\text { Endocrine Dis- } \\
\text { rupting Chemi- } \\
\text { cals (EDCs) }\end{array}$ & $\begin{array}{l}\text { Livestock farms wastewater effluent } \\
\text { (run-off and wastewater discharge } \\
\text { from intensive dairy, beef cattle, poul- } \\
\text { try pigs, and aquaculture farms). sew- } \\
\text { age treatment plants. }\end{array}$ & $\begin{array}{l}\text { EDCs' low concentration causes an increased } \\
\text { level of vitellogenesis in fish. } \\
\text { EDCs affect reproduction in fish. }\end{array}$ \\
\hline Nutrients & $\begin{array}{l}\text { Nitrogen and phosphorus fertilizers } \\
\text { used in agricultural farms and lawns, } \\
\text { animal waste, sewage treatment plants, } \\
\text { septic system, and animal manures; }\end{array}$ & $\begin{array}{l}\text { Algal bloom and eutrophication, nitrates cause } \\
\text { methemoglobinemia. }\end{array}$ \\
\hline $\begin{array}{l}\text { PAH } \\
\text { (Polycyclic } \\
\text { aromatic hy- } \\
\text { drocarbons) }\end{array}$ & $\begin{array}{l}\text { Oil and oil spills, refinery effluents, } \\
\text { aluminum smelting, domestic sewage } \\
\text { effluents, stormwater runoff, and the } \\
\text { wood preservative; }\end{array}$ & $\begin{array}{l}\text { PAHs may cause the death of fish and birds. } \\
\text { PAHs vary substantially in their toxicity to } \\
\text { aquatic organisms. PAHs affect algae, mol- } \\
\text { lusks, and other species. PAHs toxic causes } \\
\text { genetic effects and cancer in aquatic animals } \\
\text { and also kills fish, eutrophication, aesthetics. }\end{array}$ \\
\hline $\begin{array}{l}\text { PBDEs } \\
\text { (Polybrominate } \\
\text { d diphenyl } \\
\text { ethers) }\end{array}$ & $\begin{array}{l}\text { PBDEs are synthetic compounds used } \\
\text { as additives to retard fire (Flame re- } \\
\text { tardants) used in a variety of commer- } \\
\text { cial and household products (plastics, } \\
\text { textiles, carpets, polyurethane foams, } \\
\text { television sets, electronic devices, com- } \\
\text { puters, and building materials). }\end{array}$ & $\begin{array}{l}\text { PBDEs are hydrophobic, lipophilic, and bioac- } \\
\text { cumulate in the aquatic food chain and fish. } \\
\text { PBDE affects fish thyroid hormone levels and } \\
\text { Inhibited sperm production. } \\
\text { PBDE reduced cumulative egg production and } \\
\text { egg protein content, PBDE inhibited fish } \\
\text { growth causes cancer and genetic defects }\end{array}$ \\
\hline
\end{tabular}


Table 1. Continued...

\begin{tabular}{lll}
\hline Emerging pollutant & Sources & Effects \\
\hline PCBs & Aroclor, Clophen, or Kanechlor are & PCBs are highly lipophilic and bioaccu- \\
(Polychlorinated & used as dielectric fluids in electrical & mulate in aquatic organisms through the \\
biphenyls) & products such as transformers, and in & aquatic food chain and affect the thyroid \\
& hydraulic fluids, printing inks, adhe- & functions in fish. \\
& sives, and paints. & PCB toxic effects are harmful to aquatic \\
& & life. \\
\hline
\end{tabular}

prevention of water pollution by primary, secondary, or biological treatment play an important role in providing clean and clear water for the future.

Conflict of interest: The author declares that there is no conflict of interest.

\section{References}

Abdel, G.F.K., Osman, O., Bassem, S.M., Nassar, H.F., Temraz, T.A., Elhaes, H. and Ibrahim, M. (2018). Spectroscopic Analyses and Genotoxcity of Dioxins in the Aquatic Environment of Alexandria. Marine Pollution Bulletin, 127: 618-625.

APHA. (1989). Standard methods for the examination of water and wastewaters, $1^{\text {th }}$ edn, Washington D.C. American Public Health Association.

APHA. (2005). Standard methods for the examination of water and waste waters, $21^{\text {st }}$ edn, Washington D.C. American Public Health Association

APHA. (2012). Standard methods for the examination of water and waste waters, $22^{\text {nd }}$ edn, Washington D.C. American Public Health Association.

Bassem, S.M. (2020). Water pollution and aquatic biodiversity. Biodiversity International Journal, 4(1): 10-17.

Bouraie, El.M.M, Barbary, El.A.A, Yehia, M.M. and Motawea, E.A. (2010). Heavy metal concentrations in surface river water and bed sediments at Nile Delta in Egypt. Suoseura - Finnish Peatland Society, 61(1):1-12.

Cherian, K.J. and Shahare, P.C. (2011) Pollution, a threat to conservation of Biodiversity in Fresh water body of Chulband River, Gondia Dist., Maharashtra. International Journal for Environmental Rehabilitation and Conservation, 2(2): 70-78.

Fent K. (2013). Okotoxikologie. Georg Thieme Verlag, Stuttgart.

IUCN. (2019). Extinction crisis escalates: Red List shows apes, corals, vultures, dolphins all in danger. Retrieved on June, 02 2020 from https:/www.iucn.org/content/extinction-crisis-escalates-red-listshows-apes-corals-vultures-dolphins-alldanger.

Kibria, G. (2016). World Rivers in crisis: water quality and water dependent biodiversity are at risk- threats from pollution, climate change and dams development. Retrieved on June, 162020 from https://www.researchgate.net/ publica-

tion/263852254_World_Rivers_in_Crisis_Water_Quality_and_Water_Dependent_Biodiversity_Are_at_Risk_Threats_of_ Pollution_Climate_Change_and_Dams_Development

Kumar, N.J.I. (1997) Impact of pollution on aquatic biodiversity. Ecology, Environment and Conservation, 3(3-4): $209-217$.

Kumar, V., Kumar, S., Srivastava, S., Singh, J. and Kumar, P. (2018). Water quality of River Ganga with reference to physico-chemical and microbiological characteristics during Kanwar Mela 2017, at Haridwar, India: A case study. Archives of Agriculture and Environmental Science, 3(1): 58-63. 
Kumar, V., Singh, J. and Kumar, P. (Eds.). (2020). Environmental Degradation: Causes and Remediation Strategies (Vol. 1). Agro Environ Media, Publication Cell of AESA, Agriculture and Environmental Science Academy, pp. 1-227.

Leip, A., Billen, G., Garnier, J., Grizzetti, B., Lassaletta, L., Reis, S., Simpson, D., Sutton, M.A., Vries, W.D. and Weiss, F. (2015). Impacts of European livestock production: nitrogen, sulphur, phosphorus and greenhouse gas emissions, land-use, water eutrophication and biodiversity. Environmental Research Letters, 10(11): 115004.

Liong, P.C., Hamzah, W.P. and Murugan, V. (1988). Toxicity of some pesticides towards freshwater fishes. Malaysian Agricultural Journal, 54(3): 147-156.

Murty, M.N. and Kumar, S. (2011). Water Pollution in India An Economic Appraisal India Infrastructure Report. Retrieved on May, 222020 from http://www.idfc.com/pdf/report/2011/Chp-19-Water-Pollution-in-India-An-Economic Appraisal.pdf

Odum, E.P. (1954). Fundamentals of Ecology. Philadelphia: W. B. Saunder's Company, New York, pp. 383.

Pathak, J. (2018). Causes, effects and control of water pollution in India. International Journal of Academic Research and Development, 3(2): 939-942.

Poulin, R. (1992) Toxic pollution and parasitism of freshwater fish. Parasitol Today, 8(2): 58-61.

Richardson, S.D., Plewa, M.J., Wagner, E.D., Schoeny, R. and Demarini, D.M. (2007). Occurrence, genotoxicity, and carcinogenicity of regulated and emerging disinfection by-products in drinking water: a review and roadmap for research. Mutation Research/Reviews in Mutation Research, 636(1): 178-242.

Sehar, A., Ali, S., Ameen, U.S., Farid, M., Bharwana, S.A., Hannan, F. and Ahmad, A. (2014). Effect of different heavy metal pollution on fish. Research Journal of Chemical and Environmental Sciences, 2(1): 74-79.

Shreadah, M.A., Fattah, L.M.A. and Fahmy, M.A. (2015). Heavy Metals in Some Fish Species and Bivalves from the Mediterranean Coast of Egypt. Journal of Environmental Protection, 6: 1-9.

UNEP. (1992). Convention on Biological Diversity. UNEP Nairobi. Retrieved on May 152020 from https://www.cbd.int/doc/ legal/cbd-en.pdf.

Vishwanath, P.M., Pandey, P. and Bhargava, A. (2017). Water pollution - global perspective with special reference to India. Journal of Bio Innovation, 6(6): 853-863.

*****

Cite this chapter as: Uniyal, A. (2020). Deteriorating impacts of emerging water pollutants on biological diversity. In: Advances in Environmental Pollution Management: Wastewater Impacts and Treatment Technologies, Volume 1, Eds. Kumar, V., Kamboj, N., Payum, T., Singh, J. and Kumar, P., pp. 1-9, https://doi.org/10.26832/ aesa-2020-aepm-01 